\title{
Determination of the strategic competitive advantage of the footwear industry in Plaza Azul, San Mateo Atenco, State of Mexico
}

\section{Determinación de la Ventaja competitiva estratégica de la industria del calzado de la Plaza Azul, San Mateo Atenco, Estado de México}

CALDERÓN-RÍOS, Norma Otilia†**, ORDOÑEZ-HERNÁNDEZ, Lucía, AGUIRRE-BRITO, Dorian and VALDES-ORTEGA, Monserrat

Tecnológico Nacional de México/Instituto Tecnológico de Toluca

ID $1^{\text {st }}$ Author: Norma Otilia, Calderón-Ríos / ORC ID: 0000-0002-6292-4140, CVU CONACYT ID: 528227

ID $1^{\text {st }}$ Co-author: Lucía, Ordoñez-Hernández / ORC ID: 0000-0003-4357-7355, CVU CONACYT ID: 998179

ID $2^{\text {nd }}$ Co-author: Dorian, Aguirre-Brito / ORC ID: 0000-0002-3642-4767, CVU CONACYT ID: 998086

ID $3^{\text {rd }}$ Co-author: Monserrat, Valdes-Ortega / ORC ID: 0000-002-7103-7084

DOI: $10.35429 / \mathrm{JBS} .2021 .19 .7 .1 .15$

Received March 12, 2021; Accepted June 10, 2021

\begin{abstract}
The manufacture of footwear in the State of Mexico is an activity of the utmost importance, since it represents an important source of income for the community of San Mateo Atenco; in the last ten years just over $40 \%$ of family workshops have closed. Plaza Azul has also been affected with a considerable decrease in sales volume, a situation that is considered critical today. The purpose of this research is to determine the strategic competitive level of the footwear producers of the Plaza Azul and from this, to design strategies that allow them to increase their competitiveness. The present study is of a descriptive transectional type. To determine strategic competitiveness, 18 variables are evaluated. Based on the results obtained, which show that the highest optimization factor is the strength of the commercial network and the highest risk factor is the dependence on customers, proposed strategies are presented to expand their market niche to neglected sectors as well as strategies that allow them to have access to various sources of financing, to gain access to the necessary capital to expand their operations and achieve the desired competitiveness.
\end{abstract}

Competitive, Strategic advantage, Footwear industry

\begin{abstract}
Resumen
La fabricación de calzado en el Estado de México es una actividad de suma importancia, toda vez que representa una fuente de ingresos importante para la comunidad de San Mateo Atenco; en los últimos diez años poco más del $40 \%$ de los talleres familiares han cerrado. La Plaza Azul igualmente se ha visto afectada con una disminución considerable del volumen de ventas, situación que hoy día se considera crítica. Esta investigación tiene como propósito determinar el nivel competitivo estratégico de los productores de calzado de la Plaza Azul y a partir de esto, diseñar estrategias que permitan elevar su competitividad. El presente estudio es de tipo transeccional descriptivo. Para determinar la competitividad estratégica se evalúan 18 variables. A partir de los resultados obtenidos, los cuales muestran que el factor de optimización más alto es la fortaleza de la red comercial y el factor de mayor riesgo es la dependencia de los clientes, se presentan propuestas de estrategias para para ampliar su nicho de mercado a sectores desatendidos, así como estrategias que les permitan tener acceso a diversas fuentes de financiamiento, para contar con el capital necesario para ampliar sus operaciones y lograr la competitividad deseada.
\end{abstract}

Ventaja competitiva, Estratégica, Industria del calzado

Citation: CALDERÓN-RÍOS, Norma Otilia, ORDOÑEZ-HERNÁNDEZ, Lucía, AGUIRRE-BRITO, Dorian and VALDES-ORTEGA, Monserrat. Determination of the strategic competitive advantage of the footwear industry in Plaza Azul, San Mateo Atenco, State of Mexico. Journal of Business and SMEs. 2021. 7-19: 1-15

*Correspondence to Author (email: adriana_130592@ hotmail.com)

$\dagger$ Researcher contributing first author. 


\section{Introduction}

For any type of organization, regardless of its line of business, purpose or size, it is of utmost importance to recognize the qualities that distinguish it, as well as those factors that may affect its permanence in the market. In the search for answers that generate a competitive advantage to the shoe producers of Plaza Azul de San Mateo Atenco, the present research is carried out.

The first part of this research describes the background of the footwear industry at national and regional level, as well as the theoretical foundations about competitiveness and determination of the strategic competitive advantage, SWOT situational analysis and the impact of Covid-19 in the footwear sector of San Mateo Atenco; subsequently, the problem that supports this research is described, which refers to the importance of knowing the competitive position of the footwear manufacturing industry.

The methodology used is of a descriptive transectional type because, through the analysis, the variables that determine the strategic competitiveness of the footwear industry of Plaza Azul de San Mateo Atenco were described. By means of the SWOT situational analysis it was possible to determine the strategic balance for each of the variables described; finally, conclusions are presented on the strategic competitive position of Plaza Azul de San Mateo Atenco and a proposal is made for strategies that support the improvement of its strategic competitiveness and its position in the market. It should be noted that this article is the product of a research project focused on the Plaza Azul footwear industry in San Mateo Atenco, Mexico, which is still in progress.

For this reason, the background of this sector described in the frame of reference was taken from the article Zenteno et al (2019), Estrategias de la Mezcla de Mercadotecnia de la Industria de Calzado en San Mateo Atenco Plaza Azul, due to the fact that these are the same facts that are reported. Said article is mentioned in the reference sources section.

\section{Frame of Reference}

The earliest history of shoemaking in Mexico dates back to the 17th century, in the state of Guanajuato. The oldest information recorded in the Municipal Historical Archive regarding shoemaking in the Villa de León dates back to 1645. Andrés González Cabildo is the name of the oldest shoemaker, according to information from the archives of the Chamber of the Footwear Industry of the State of Guanajuato (CICEG).

It is important to review the history and evolution of the footwear industry in Mexico by highlighting some facts from the CIGEC archive. In 1719, the first census of the Villa de León was taken, showing the existence of 36 houses in which shoes were manufactured by Spaniards, Indians and mulattos. Later, in 1869, there were 50 "shoe factories", that is to say, workshop houses in which families formed units of artisan production. The first formal shoe factory on record began operations in 1872. By 1900, 17\% of León's economically active population worked in the shoe industry, making it, along with the textile industry, León's most important economic activity.

Small-scale manufacturing establishments were the pivot for the development of footwear manufacturing in Mexico between 1920 and 1930. The creation of productive workshops began to take place at a dizzying rate due to demand, with local capital acting as the main responsible for those areas becoming the main regions of the national footwear industry from that time on. On May 24, 1926, the Union de Fabricantes de Calzado de Leon was established, whose founding president was Mr. Jose Padilla Moreno and the first secretary was Mr. Ignacio L. Hernandez.

In the 1950's the mechanization of the production process began and the technical principles brought from abroad were integrated. Shoe manufacturers promoted their products individually. At the end of the decade, the directors of the National Chamber of the Footwear Industry began to organize a product exhibition, following the example of the North American model of commercial fairs. The first national exhibition was held in Mexico City in 1956. 
In 1966, at a time when it was necessary to reactivate the sale of footwear, the $\mathrm{X}$ National Footwear Exhibition was held in Leon, already known as the Mexican Footwear Industry Exhibition, an event that the local press announced as the one that would show "all its industrial potential in the most ambitious exhibition held until then". The event, the result of the efforts of several visionaries, ceased to be held due to differences between the representatives of the different Chambers. However, the model was so successful that the Leonese producers decided to continue it.

The manufacturers of the Footwear Chamber of the State of Jalisco initiated in 1977 their "Spring National Exposition", being the venue the city of Guadalajara, Jalisco. Five years after the Salón de la Piel y el Calzado (SAPICA) opened its doors in León, ANPIC, the first international supply fair, was born in 1979.

Thanks to this path and the structure that was established over the years, the Chamber of the Footwear Industry of the State of Guanajuato planned and programmed the implementation of a special department that would serve as support for the activities that the committee in turn determined to carry out. Based on this programming, in 1980 the first steps were taken to incorporate human and material resources that would constitute the department in charge of the exposition. Thus, as of the 8th SAPICA Event, the Chamber already had the foundations to achieve its objective. It was in 1982 that SAPICA was named the National Footwear Fair.

The acceptance of this product in the national market was such that the National Chamber of the Footwear Industry (CNIC) reached its historical maximum production level with the production of 317 million pairs of shoes, of which $7.5 \%$ were exported to the U.S. market. However, the national crisis of the eighties irremediably affected this sector and according to Zarur (1993) "While in 1980 per capita consumption was estimated at 5.6 pairs per year; in 1989, at the end of the decade it was 2.5 pairs of shoes, as a result of the loss of purchasing power of consumers while footwear prices rose significantly, given the increases in production costs".
In 1999 , on its 25 th anniversary, SAPICA expected 10,000 buyers with visits from 25 countries around the world, and signed an agreement with CUOROMODA, then the first fair in Latin America, in order to make the two fairs known in neighboring countries and in their own.

According to INEGI figures, at the end of the 90's, 70 million pairs of shoes were produced per year and 73,439 workers were directly employed. In order to position the sector as a globally recognized producer, actions had to be taken to promote it, which were carried out by businessmen, chambers, research centers and the government. Because of this, and because it is a basic consumption item and an important source of employment in the country, the footwear industry was given priority in the National Industrial Development Plan of the Federal Government 2000-2006, during the term of President Vicente Fox Quezada.

The 2009 economic census (INEGI) recorded 7,398 economic units dedicated to footwear manufacturing, representing $1.7 \%$ of total manufacturing industries, which employed 112,727 people, accounting for $2.4 \%$ of total employment in the manufacturing sector. The micro establishments of this sector represented $78.5 \%$, employing $19 \%$ of the total personnel and generated $6.2 \%$ of the total gross production, in comparison with the large companies, which only represented $1 \%$ and employed three out of every ten employed persons and generated almost $40 \%$ of the production. As for the total footwear production, $87 \%$ was destined for private consumption and the rest was for intermediate demand (domestic or foreign) referring to commerce, freight transportation, fabric manufacturing, to footwear manufacturing itself, paint manufacturing, coatings, adhesives and sealants, among others.

|During 2013, 2014 and 2015, the footwear industry only generated revenues in the amounts of $\$ 17,436, \$ 17,462$ and $\$ 18,013$ (million pesos) and in terms of employed personnel, the figures were 93,$291 ; 92,877$ and 94,601 , respectively. The contribution to the GDP decreased, as it averaged $0.6 \%$ in those years. According to data provided by the federal government. 
The slowdown in the economic figures generated by the footwear industry is evident, and some situations can be observed that have contributed to this. The first important fact is China's entry into the World Trade Organization (WTO) at the end of 2001 and the other, Mexico's entry into the Trans-Pacific Economic Cooperation Agreement on February 4, 2016, called the Trans-Pacific Partnership (TPP).

Referring to China and its incursion into the WTO, this country has managed to enter and maintain important advantages in sectors such as footwear, textiles, electronics, toys, information technologies, among others. The strategy generated by this country, according to Kerber (2002) "[...] in the case of laborintensive industries, was often focused on learning the modus operandi to replace foreign producers with domestic producers in the medium term and then displace them from the markets they dominate. This is the case of the footwear industry where Chinese brands have been progressively incorporated". Other data that are highlighted are enunciated below.

Esquivel (2015) "China is the world's leading footwear producer, manufacturing 5.5 billion pairs of footwear and exporting 3.1 billion pairs annually. In order of importance, China ranks first in foreign sales, followed by India with 682 million, Brazil with 520 million, Italy with 425 million, Indonesia with 318 million, Turkey with 270 million and Mexico ranks seventh with 170 million. Ten years ago Mexico imported only 3.0\% of its domestic footwear consumption, now that consumption has increased to $20 \%$ of the total."

Olvera (2018) "Trade exchange between Mexico and the United States fell from 81 percent in the 1990s to 63 in 2016, a year after Republican President Trump issued since the campaign a protectionist speech. In contrast, Mexico's trade with China rose from -1 percent to 10 percent in 2016, according to the National Autonomous University of Mexico's Center for China-Mexico Studies that has researched the trilateral U.S.-China-Mexico relationship." And it adds that in 2017 while China sold us 67 billion 741 million dollars (computer and communication technology products, clothing, footwear, electrical appliances), Mexico only exported 6 billion 61 million dollars to it (computer, electronic, communication and auto parts products).
As for the TP (Trans-Pacific Partnership Agreement), initially formed by the following countries: Australia, Brunei, Canada, Chile, the United States, Japan, Malaysia, Mexico, New Zealand, Peru, Singapore and Vietnam. These countries accounted for about $40 \%$ of world GDP and $25 \%$ of international trade, and sought to create a new economic bloc in the Pacific by reducing approximately 18,000 customs tariffs. The aim was to change the rules on the exchange of goods and services. However, at the end of January 2017, the United States withdrew. This led to a rearrangement of the treaty and on March 8, 2018, it was signed again, now under the name of Comprehensive and Progressive Agreement for Trans-Pacific Partnership (CPTPP), with the eleven remaining countries.

In an interview conducted by Expansión Magazine in February 2018 with Mr. Alejandro Gómez, executive president of the Guanajuato State Chamber of Industry, he commented "We are much more concerned about the CPTPP, because as it is drafted it will allow Vietnam to produce footwear using inputs from China (which are up to $50 \%$ cheaper than those available in Mexico), and export them to the Mexican market duty free. In addition, wages in Vietnam are up to $50 \%$ lower than those paid in the sector. We will not be able to compete with this mix of cheap inputs and low wages".

The article highlights that Vietnam is the second largest footwear manufacturer globally, after China, and the bulk of its production is for export. So far, Vietnamese footwear pays a tariff to enter Mexico, which balances out the low costs. But once the CPTPP is signed, Vietnamese footwear will enter a phase of tariff relief. This has Mexican manufacturers worried, as the Asian product could displace the 235 million pairs sold by Mexican manufacturers in Mexico.

In view of this situation, Ernesto Acevedo Fernández, Mexico's Undersecretary of Industry and Commerce, stated in a conference (February 25, 2019) that in view of the adverse situation faced by the footwear industry, the following actions were immediately proposed: the signing of two Presidential Decrees temporarily establishing a 25 percent or 30 percent tariff on footwear imports. This was published in the Official Gazette of the Federation on April 10, 2019.

CALDERÓN-RÍOS, Norma Otilia, ORDOÑEZ-HERNÁNDEZ, Lucía, AGUIRRE-BRITO, Dorian and VALDES-ORTEGA, Monserrat. Determination of the strategic competitive advantage of the footwear industry in Plaza Azul, San Mateo Atenco, State of Mexico. Journal of Business and SMEs. 2021 
After this background information that has impacted the footwear industry at the national level and with the purpose of knowing the competitiveness of the companies in this sector at the regional level, we proceed to describe the object of study of this research, which is composed of 366 footwear manufacturers and traders established in Plaza Azul, in the Municipality of San Mateo Atenco, State of Mexico.

The State of Mexico is divided into 125 municipalities, of which only 6 contribute to the economic sector of footwear, these are home to $81 \%$ of the establishments and $80 \%$ of the employment. These municipalities are Cuautitlán, Cuautitlán Izcalli, Naucalpan, Tlalnepantla, San Mateo Atenco and Toluca, being the most important of them due to the number of companies and the level of employment it generates: San Mateo Atenco.

According to the Ministry of Economy, $87 \%$ of the companies in the footwear industry in the State of Mexico are classified as microenterprises, almost $7 \%$ as small companies, $4.55 \%$ are medium-sized and $1 \%$ are large. San Mateo Atenco is home to just over $40 \%$ of the footwear industry in the State of Mexico. This municipality has a population of approximately 73,000 inhabitants and $75 \%$ of the families are dedicated to shoemaking, both artisanal and industrial. The history of the shoe industry in this jurisdiction is divided into three periods:

1. 1900-1912, the production was generated manually.

2. 1913-1931, mechanical machines are used: the first one, to sew the cut, the second one, to sew the sole and the third one, a machine with a pedal.

3. 1932-1959, electric machines were used and the first shoe factories were established.

San Mateo Atenco has also suffered from the events described above regarding China and treaties with other countries. The impact can be seen in the serious decrease in sales. The president of the San Mateo Atenco Footwear Producers group (Procasma), Mr. Luis Gonzaga González Tapia, at the end of June 2019 has stated to the media that the footwear industry in this municipality is at risk due to flooding in the area and the sale of pirated footwear from China, which has caused the closure of $20 \%$ of footwear workshops.
"It has been very complicated to shield a border so that shoes do not enter clandestinely because, with the tariff measures, if they entered legally, prices would rise, but it is contraband and it is unfair competition, because we struggle with the payment of taxes, insurance affiliations and other obligations as taxpayers," said the Procasma representative.

Regarding the contingency situation originated by the SARS-CoV-2 that causes the COVID-19 disease, the representative of Plaza Azul, Ismael Gutiérrez Sánchez pointed out and exposed that, in spite of carrying out all the sanitary measures imposed by the Secretary of Health of Mexico, the business is not recovering yet because the attendance is "lukewarm" and many visitors arrive and leave without making any purchase despite prices that become a bargain. (Perez, 2020)

In addition to this, the leader added: "The situation will not improve in the short term, there is no improvement in attendance of buyers and sale of products", so they are still waiting for the local city council to deposit the money they promised to manufacture 4,500 pairs of shoes for Atenco students of preschool, elementary and high school as part of this pandemic to revive the economy of shoe workers and other merchants in the municipality. The Plaza Azul vendors are responsible for the manufacture of these four thousand five hundred pairs of shoes of the almost 10 thousand that the mayor's office requested from other manufacturers at a uniform cost of 350 pesos per pair; however, the prolongation of the start of classes until now indefinitely also originated the postponement of the deposit to the shoemakers. Therefore, the outlook is quite bleak.

In a globalized world where services and products are highly diversified and available in virtual markets, companies compete in the search for those differentiating elements that allow them to generate a competitive advantage and thus continue to be preferred by customers. Some studies on the subject are listed below.

Publishing, Marketing, (2007) "In order to survive in a competitive market, companies must necessarily outperform their competitors and, therefore, need to create and consolidate sustainable competitive advantages".

CALDERÓN-RÍOS, Norma Otilia, ORDOÑEZ-HERNÁNDEZ, Lucía, AGUIRRE-BRITO, Dorian and VALDES-ORTEGA, Monserrat. Determination of the strategic competitive advantage of the footwear industry in Plaza Azul, San Mateo Atenco, State of Mexico. Journal of Business and SMEs. 2021 
For this author, competitiveness comprises three aspects: economic rationality, capacity for coordination and adaptation to the environment, and management and organizational capacity. Finally, being competitive implies permanently creating barriers against competitors; it is about taking the initiative and taking the necessary steps to achieve high levels of productivity and efficiency in the management of resources in order to reach high levels of competitiveness.

For Hamel \& Prahalad (2005) precursors of the resource theory, in their article "Strategic Purpose" they mention that competitive advantage is the need to accelerate the organization's learning to overcome competitors in the construction of new advantages. And they emphasize that the strategist's goal is not to find a niche within the industry, but to create a new space that suits the company's particular strengths and resources, i.e., a space not yet explored. It is a process of mastering core competencies and overcoming environmental barriers to achieve an advantage that will allow the company to achieve its objectives, even though these may be longer term.

Garcia, Prieto, \& Sanz (2014) in their article Factores de competitividad organizacional: su gestión para la sostenibilidad empresarial, analyze the factors that impact on the competitiveness of organizations, for this they used hermeneutics through literature review, which allowed determining the elements that strengthen competitiveness, concluding that the human factor, innovation, financial resources, information and communication technology, environmental management and differentiating factors, constitute competitiveness factors whose proper management strengthens the sustainability of companies over time. The same authors cite Sarmiento, Sánchez and Cruz (2009), who define competitiveness as the company's capacity to penetrate, consolidate or expand its market share. This capacity is expressed in skill, administrative action, timely use of installed capacity, adequate management of financial, human and material resources, but above all in the perception of market signals, which, when implemented in a timely manner, allow the company to identify consumer needs, resize the scale of production or services offered, and redesign market strategies for positioning.
Sáez de Viteri (2000) in his article "El potencial competitivo de la empresa: recursos, capacidades, rutinas y procesos de valor añadido" presents a dynamic model for the study of competitive advantage, based on the theory of resources and capabilities, which postulates that the sustained competitive advantage of companies lies in the value generators, understood as the resources, capabilities and routines that support core competencies.

These distinctive core competencies must be sought both internally and externally. Introspection to see what the company knows how to do and how, and from the customers' appreciation of the value the company is adding. Sometimes the customer's appreciation of the company's products does not coincide with what the company believes is a source of differentiation or technological excellence. The concept and component of distinctive core competencies are shown in Table 1.

\begin{tabular}{|c|c|}
\hline \multicolumn{2}{|c|}{ Strategic Competence } \\
\hline Concept & Componentes \\
\hline $\begin{array}{l}\text { Management and coordination } \\
\text { of value drivers to build a } \\
\text { competitive strategy that meets } \\
\text { stakeholder demands and creates } \\
\text { added value for customers in } \\
\text { multiple markets. }\end{array}$ & $\begin{array}{l}\text { - What the company } \\
\text { wants to be and where } \\
\text { it wants to go = } \\
\text { Vision, mission and } \\
\text { objectives. } \\
\text { - What it is and what it } \\
\text { knows how to do = } \\
\text { Resources. } \\
\text { - What it is capable of } \\
\text { being and doing = } \\
\text { Capabilities. } \\
\text { - Management } \\
\text { coordination of value } \\
\text { drivers }\end{array}$ \\
\hline \multicolumn{2}{|c|}{ Competencia Tecnológica } \\
\hline Concept & Components \\
\hline $\begin{array}{l}\text { The ability to design, purchase, } \\
\text { manufacture and sell }\end{array}$ & $\begin{array}{l}\text { - Stock of technologies } \\
\text { - Know-how to apply } \\
\text { them } \\
\text { - Innovation capacity }\end{array}$ \\
\hline \multicolumn{2}{|c|}{ Competencia de Personal } \\
\hline Concepto & Components \\
\hline $\begin{array}{l}\text { The organization's Etos, the set } \\
\text { of people's capabilities, known } \\
\text { or not and used or not. }\end{array}$ & $\begin{array}{l}\text { - Aptitude or } \\
\text { knowledge } \\
\text { - Craft or skills } \\
\text { - Attitude or behavior }\end{array}$ \\
\hline \multicolumn{2}{|c|}{ Competencia organizativa } \\
\hline Concept & Components \\
\hline $\begin{array}{l}\text { Coordination of value generators } \\
\text { through the company's } \\
\text { organizational structure. }\end{array}$ & \begin{tabular}{|l}
- \\
-
\end{tabular} $\begin{array}{l}\text { Task design } \\
\text { Routines or } \\
\text { methods } \\
\text { Power structure } \\
-\begin{array}{l}\text { Production and } \\
\text { information system }\end{array} \\
\end{array}$ \\
\hline
\end{tabular}

Table 1 Concept and components of core competencies Source: Adapted from Sáez de Vierteri (2000)

CALDERÓN-RÍOS, Norma Otilia, ORDOÑEZ-HERNÁNDEZ, Lucía, AGUIRRE-BRITO, Dorian and VALDES-ORTEGA, Monserrat. Determination of the strategic competitive advantage of the footwear industry in Plaza Azul, San Mateo Atenco, State of Mexico. Journal of Business and SMEs. 2021 
The author also mentions that value drivers must be valuable in such a way that they can exploit an opportunity or neutralize a threat, rare in the sense that they are not possessed by other companies, inimitable because they have been shaped internally within the organization and therefore unique and irreplaceable.

The competitive position, as a preliminary phase of the dynamic model for the study of competitive advantage, arises from the strategic analysis and will be the result of comparing the key competencies required by the competition (external analysis) with the key competencies possessed by the company (internal analysis).

Porter (2007) states that competitive advantage results from the ability of organizations to execute the required activities at a lower cost than rivals or to execute some activities in a unique way that creates value for the customer and allows the company to position itself, he also establishes within the concept of value chain the need to have a mechanism to detect the potential of resources as a source of sustained competitive advantage.

According to Ramirez, (2009) one of the fundamental aspects of strategic planning is the situational analysis, also known as SWOT analysis (strengths, weaknesses, opportunities and threats), which enables the collection and use of data that allows to know the operating profile of a company at a given time, and from this to establish an objective diagnosis for the design and implementation of strategies to improve the competitiveness of an organization, it is important to clarify that this type of analysis is applicable to any type of company regardless of its size or nature.

As part of the conclusions of the research article, Ramírez comments that the improvement proposals should be oriented both towards reducing weaknesses, reinforcing and maintaining strengths and searching for suitable opportunities for the company's capabilities, as well as providing a defense against external threats. Accepted improvements must be congruent with the conditions or means of operation of the company, in order to increase its abilities and resources. It also defines that a competitive advantage constitutes a special skill or ability that a company manages to develop, and that places it in a position of preference in the eyes of the market.
A product or service that the market perceives as unique and determining, constitutes a differential factor in the characteristics of a company. For a competitive advantage to be truly useful, it must also be sustainable, i.e. the company must be able to maintain it for a reasonable period of time; to achieve this, the advantages identified must meet two criteria: a) have their origin in a strength or strong point of the company, not in a passing circumstantial event, and $b$ ) have such characteristics that it is difficult for the competition to imitate in the short term.

Betancourt Guerrero, (2014) refers that the basic model proposed in the early sixties by a group of professors at Harvard Business School, in a first phase, the formulation of strategies rests on the well-known SWOT model, which records the alignment that must exist between the strengths and weaknesses of the organization, derived from its internal evaluation, and the opportunities and threats of the environment, derived from its external evaluation. In the words of the proponents of this model, the economic strategy will be considered as the fit between the qualifications and the opportunity that positions a company in its environment. Once the strategy has been evaluated and selected, the next phase corresponds to its implementation or putting into practice, in accordance with the resources allocated in the preceding phase.

In this research work, we propose to determine the competitive potential of the footwear producers of Plaza Azul through the theory of resources and capabilities, which is based on the fact that it is the company's own resources and capabilities that lead it to select the opportunities, yet to be explored, for which it is best equipped to define a sustainable competitive advantage.

\section{Problem Statement}

The first data on footwear manufacturing in Mexico dates back to the 17 th century. With a presence of more than 4 centuries, footwear manufacturing in Mexico is an important commercial activity in our country, which generates a highly competitive supply chain, made up of nearly 7,400 manufacturing establishments.

CALDERÓN-RÍOS, Norma Otilia, ORDON̄EZ-HERNÁNDEZ, Lucía, AGUIRRE-BRITO, Dorian and VALDES-ORTEGA, Monserrat. Determination of the strategic competitive advantage of the footwear industry in Plaza Azul, San Mateo Atenco, State of Mexico. Journal of Business and SMEs. 2021 
According to data published by the Ministry of Economy, 94\% of the value of footwear production is concentrated in four Mexican states: Guanajuato $70 \%$, Jalisco $15 \%$, the State of Mexico 5\% and Mexico City 3\%. Most of the footwear manufactured in Mexico is for domestic consumption, which represents $87 \%$ of total production.

The Mexican footwear industry has been seriously affected by different events, such as the crises of 1982 and 1994, as well as the entry into force of several international trade agreements, being one of the productive sectors that suffered the most from Mexico's trade liberalization process, which caused both its installed capacity and its production to decline. This situation has worsened in recent years.

On the other hand, the COVID-19 pandemic has had a negative impact on the country's economy. Alegría, (2020), published that the footwear sector has totaled an economic loss of 2,800 million pesos during the two months of the forced stoppage due to the coronavirus pandemic.

The footwear industry in San Mateo Atenco has not been excluded from such affectation, a worrying situation for manufacturers since it is one of the main engines of the economy. Today it is important to know more specifically how to take advantage of the opportunities that arise in the environment by making use of the company's strengths, taking into account the weaknesses and threats. To do this, it is necessary to carry out the strategic balance of the company, in this case of Plaza Azul.

Therefore, it is necessary to evaluate the competitiveness, taking into account 4 variables: Strategic Competitiveness, Technology, personnel and Organizational Structure, being the objective of this research to evaluate first the strategic competence, considering the 18 factors mentioned in the method. By evaluating the impact of these factors, it will be possible to determine the real conditions of each variable, determine the factors of optimization and risk, and from them establish strategies that support the increase of strategic competitiveness and improve its position in the market. It is worth mentioning that most footwear manufacturers have an empirical management.

\section{Methodology}

In this work the research design is descriptive transectional type because, through the analysis, the description of the variables that determine the strategic competitiveness of the footwear manufacturers of Plaza Azul de San Mateo Atenco will be carried out, for which primary data are obtained. According to Hernández, Fernández and Baptista (2010) the type of study corresponds to the so-called descriptive one, which seeks to specify the properties, characteristics and profiles of people, groups, communities or any other phenomenon that is subjected to analysis. In turn, descriptive crosssectional designs, which aim to investigate the incidence of the modalities or levels of one or more variables in a population, are purely descriptive studies.

The procedure consists of locating one or more variables in a group of people, living beings, objects, situations, contexts, phenomena, communities, etc. and providing their description. As for the references or primary sources, these provide first-hand data, such as interviews or surveys.

Based on the study problem posed and in correspondence with the state of the art, the principles proposed by Ramirez (2009) will be followed; this procedure does not contemplate the necessary elements to give statistical validity to the research, elements that are incorporated in the present investigation. In addition to the determination of the strategic balance, the SWOT matrix is elaborated where the proposed strategies are developed in order to increase the strategic competitiveness of the footwear manufacturers of Plaza Azul.

In order to facilitate the understanding and practical application, the detailed procedure that was carried out is shown below:

1. Identification of the analysis criteria. According to Sáez de Vierti (2000), the strategic competitive position is the result of comparing the key competencies demanded by the competition (external analysis) with the key competencies possessed by the company (internal analysis). Strategic competitiveness is defined as the result of the following 18 variables: 
1. Strategic interest to remain in the sector.

2. Image and prestige.

3. Location and facilities.

4. Production volume.

5. Market share.

6. Strength of the commercial network.

7. Profitability.

8. Financial capacity.

9. Vulnerability to changes in demand.

10. Barriers to exit from the company.

11. Barriers to mobility within the group.

12. Customer loyalty.

13. Customer dependence.

14. Cost of switching for customers.

15. Backward integration of customers.

16. Control of raw materials.

17. Dependence on suppliers.

18. Forward integration of suppliers.

2. Determination of the actual conditions of action in relation to the internal and external variables of the analysis.

a) Delimitation of the field of action. The study will be carried out taking as its universe the footwear producers of the Plaza Azul of San Matero Atenco. It was determined that there are currently a total of 324 manufacturers, information that was provided by $\mathrm{Mr}$. Ismael Gutiérrez Sánchez, president of the Plaza Azul Association in an interview with a member of the research group.

b) Determination of the sample size. Since the number of shoe manufacturers in the Plaza Azul of San Mateo Atenco is known, the formula for determining the sample size of a finite population was used (Munch \& Ángeles, 1998). (Munch \& Ángeles, 1998).

$n=\frac{k^{2} * p * q * N}{\left(e^{2}(N-1)\right)+k^{2} * p * q}$

Where:

$\mathrm{N}=324$

$\mathrm{k}=1.96 \mathrm{Z}$-value for a confidence level of $95 \%$.

$\mathrm{p}=0.5$ probability of success (determining

Strategic Competitiveness)

$\mathrm{q}=0.5$ probability of failure (determine

Strategic Competitiveness)

$\mathrm{e}=0.05$ maximum permissible error $n=\frac{(1.96)^{2} *(0.5) *(0.5) *(324)}{\left((0.05)^{2}(324-1)\right)+(1.96)^{2} *(0.5) *(0.5)}=176.01$

Given the impossibility of carrying out the surveys previously calculated due to the current conditions of the Covid 19 pandemic caused by the SARS-CoV-2 virus, it was decided to work with a $90 \%$ confidence level and accept a $20 \%$ error. It was decided to work with a confidence level of $90 \%$ and to accept an error of $20 \%$. Thus, the sample size was determined as follows:

$n=\frac{(1.645)^{2} *(0.5) *(0.5) *(324)}{\left((0.20)^{2}(324-1)\right)+(1.96)^{2} *(0.5) *(0.5)}=16.12$

$n=16$

Where:

$\mathrm{N}=596$

$\mathrm{k}=1.645 \mathrm{Z}$ value for $90 \%$ confidence level

$\mathrm{p}=0.5$ probability of success (determining

Strategic Competitiveness)

$\mathrm{q}=0.5$ probability of failure (determine

Strategic Competitiveness)

$\mathrm{e}=0.20$ maximum permissible error

c) Collection of information. The structured interview technique will be used, for which a questionnaire was designed consisting of a set of strategically planned questions regarding the variables to be measured. (Hernández, Fernández, \& Baptista, 2010). The interviews were carried out using the available media: Google Duo platform, WhatsApp and Zoom.

Given that the list of strengths (F), weaknesses (D), opportunities (O) and threats (A) can be very long, it was limited to consider only the two most relevant in each section. For the selection of the elements that make up the sample (footwear manufacturers), convenience sampling was used, in which the elements to be sampled are selected because they are accessible through existing contacts. (Munch \& Ángeles, 1998).

3. Assignment of a weighting for each of the strengths, opportunities, weaknesses and threats. 
For each of the factors mentioned in point 1 , the interviewees were asked to assign a rating of 1,3 or 5 : where 5 denotes the highest level of performance, 3 the medium level and 1 the lowest level. In this way, the differences between them can be established in order to establish a hierarchy.

4. Calculation of the results. Based on the average score obtained for each variable, a matrix was prepared with the totals and the individual contribution of each variable.

5. Determination of the strategic balance. The strategic balance (BE) is the ratio between the optimization factor (FO) and the risk factor (FR).

The optimization factor indicates the favorable position of the organization with respect to its competitive assets and the circumstances or events that can potentially be a source of competitive advantage in the near future. The risk factor shows an unfavorable position of the organization, i.e. it shows a competitive liability coupled with conditions that limit the organization's competitive position.

$\mathrm{FO}=\mathrm{F}+\mathrm{O}$

$\mathrm{FR}=\mathrm{D}+\mathrm{A}$

$\mathrm{BE}=\mathrm{FO}-\mathrm{FR}$

An organization's strategic balance sheet is better as long as the difference between the optimization factor exceeds the risk factor.

6. Preparation of the SWOT matrix and presentation of proposals. The answers of the interviewees were concentrated in a matrix to be later plotted. Based on the previous results, the SWOT matrix was prepared and from it conclusions were drawn regarding the general situation of the footwear industry with respect to strategic competitiveness, as well as the individual contribution of each of the variables studied. Finally, the SWOT matrix constitutes the basis for the elaboration of the proposals of competitive strategies in order to strengthen the strategic competitiveness to contribute to the success of the footwear industry of Plaza Azul, San Mateo Atenco, State of Mexico.

\section{Results}

The findings presented in this section describe the strategic variables that are considered relevant in the performance of the company, represent a risk or an opportunity in the future and have an impact on the strategic competitiveness of the footwear manufacturers of Plaza Azul in San Mateo Atenco, which make up the study sample. The results presented are the product of the information obtained through the structured interviews.

The results matrix was prepared based on the average score obtained for each variable. Table 2 shows the total weighting of the strengths, weaknesses, opportunities and threats.

\begin{tabular}{|c|c|c|c|c|}
\hline Strategic variables & $\mathbf{F}$ & D & $\mathbf{0}$ & A \\
\hline \multirow{2}{*}{$\begin{array}{l}\text { 1. Strategic interest in remaining in } \\
\text { the industry }\end{array}$} & 60 & 64 & 54 & 56 \\
\hline & $26 \%$ & $27 \%$ & $23 \%$ & $24 \%$ \\
\hline \multirow[t]{2}{*}{ 2. Image and prestige } & 66 & 24 & 56 & 68 \\
\hline & $31 \%$ & $11 \%$ & $26 \%$ & $32 \%$ \\
\hline \multirow[t]{2}{*}{ 3. Location and facilities } & 50 & 56 & 52 & 40 \\
\hline & $25 \%$ & $28 \%$ & $26 \%$ & $20 \%$ \\
\hline \multirow[t]{2}{*}{ 4. Production volume } & 48 & 64 & 52 & 64 \\
\hline & $21 \%$ & $28 \%$ & $23 \%$ & $28 \%$ \\
\hline \multirow[t]{2}{*}{ 5. Market share } & 68 & 62 & 58 & 50 \\
\hline & $29 \%$ & $26 \%$ & $24 \%$ & $21 \%$ \\
\hline \multirow{2}{*}{$\begin{array}{l}\text { 6. Strength of the commercial } \\
\text { network }\end{array}$} & 74 & 42 & 62 & 62 \\
\hline & $31 \%$ & $18 \%$ & $26 \%$ & $26 \%$ \\
\hline \multirow[t]{2}{*}{ 7. Profitability } & 76 & 64 & 46 & 56 \\
\hline & $31 \%$ & $26 \%$ & $19 \%$ & $23 \%$ \\
\hline \multirow[t]{2}{*}{ 8. Financial capacity } & 58 & 40 & 54 & 54 \\
\hline & $28 \%$ & $19 \%$ & $26 \%$ & $26 \%$ \\
\hline \multirow{2}{*}{$\begin{array}{l}\text { 9. Vulnerability to changes in } \\
\text { demand }\end{array}$} & 60 & 54 & 34 & 52 \\
\hline & $30 \%$ & $27 \%$ & $17 \%$ & $26 \%$ \\
\hline \multirow[t]{2}{*}{ 10. Barriers to enterprise mobility } & 38 & 44 & 52 & 66 \\
\hline & $19 \%$ & $22 \%$ & $26 \%$ & $33 \%$ \\
\hline \multirow{2}{*}{$\begin{array}{l}\text { 11. Barriers to mobility within the } \\
\text { group }\end{array}$} & 42 & 44 & 58 & 62 \\
\hline & $20 \%$ & $21 \%$ & $28 \%$ & $30 \%$ \\
\hline \multirow[t]{2}{*}{ 12. Customer loyalty } & 58 & 50 & 40 & 66 \\
\hline & $27 \%$ & $23 \%$ & $19 \%$ & $31 \%$ \\
\hline \multirow[t]{2}{*}{ 13. Dependence on customers } & 60 & 74 & 50 & 70 \\
\hline & $24 \%$ & $29 \%$ & $20 \%$ & $28 \%$ \\
\hline \multirow[t]{2}{*}{ 14. Cost of change for customers } & 50 & 32 & 68 & 56 \\
\hline & $24 \%$ & $16 \%$ & $33 \%$ & $27 \%$ \\
\hline \multirow[t]{2}{*}{ 15. Customer backward integration } & 60 & 48 & 52 & 42 \\
\hline & $30 \%$ & $24 \%$ & $26 \%$ & $21 \%$ \\
\hline \multirow[t]{2}{*}{ 16. Control of raw materials } & 68 & 48 & 38 & 60 \\
\hline & $32 \%$ & $22 \%$ & $18 \%$ & $28 \%$ \\
\hline \multirow[t]{2}{*}{ 17. Dependence on suppliers } & 40 & 48 & 46 & 34 \\
\hline & $24 \%$ & $29 \%$ & $27 \%$ & $20 \%$ \\
\hline \multirow{2}{*}{$\begin{array}{l}\text { 18. Forward integration of } \\
\text { suppliers }\end{array}$} & 64 & 48 & 66 & 58 \\
\hline & $27 \%$ & $20 \%$ & $28 \%$ & $25 \%$ \\
\hline \multirow[t]{2}{*}{ Total } & $\begin{array}{r}1,04 \\
0 \\
\end{array}$ & 906 & 938 & $\begin{array}{r}1,01 \\
6 \\
\end{array}$ \\
\hline & $27 \%$ & $23 \%$ & $24 \%$ & $26 \%$ \\
\hline
\end{tabular}

Table 2 Global situational analysis and by variable Source: Own Elaboration 
The information in Table 2 is analyzed horizontally, showing the percentage of participation of the company's internal and external conditions for each of the 18 variables that determine strategic competitiveness. For example, for variable 2 Image and prestige, its strengths represent $31 \%$; its weaknesses $11 \%$; opportunities represent $26 \%$ and threats $32 \%$.

On the other hand, if the analysis is carried out vertically, the company's strengths, weaknesses, opportunities and threats can be determined in general terms, as shown in graph 1 .

Global situational analysis SWOT

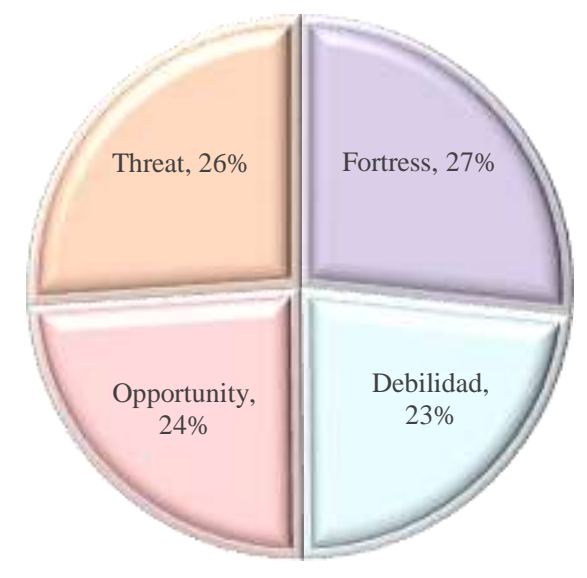

Graphic 1 Global SWOT situational analysis Source: Own Elaboration

Subsequently, the overall strategic balance (BE) was determined by variable, which is the relationship between the optimization factor (FO) and the risk factor (FR).

The results are shown in Table 3. In the tables and graphs presented below, the strategic variables are listed from 1 to 18 and correspond in numbering to those presented in Table 2, for a better visualization of the data.

\begin{tabular}{|c|c|c|c|}
\hline $\begin{array}{l}\text { Strategic } \\
\text { variables }\end{array}$ & $\begin{array}{l}\text { Optimization } \\
\text { factor (FO) }\end{array}$ & $\begin{array}{c}\text { Risk } \\
\text { factor } \\
\text { (FR) }\end{array}$ & $\begin{array}{c}\text { Balance } \\
\text { (BE) }\end{array}$ \\
\hline \multirow[t]{2}{*}{1} & 7.13 & 7.50 & -0.38 \\
\hline & $49 \%$ & $51 \%$ & $-2 \%$ \\
\hline \multirow[t]{2}{*}{2} & 7.63 & 5.75 & 1.88 \\
\hline & $57 \%$ & $43 \%$ & $14 \%$ \\
\hline \multirow[t]{2}{*}{3} & 6.38 & 6.00 & 0.38 \\
\hline & $52 \%$ & $48 \%$ & $4 \%$ \\
\hline \multirow[t]{2}{*}{4} & 6.25 & 8.00 & -1.75 \\
\hline & $44 \%$ & $56 \%$ & $-12 \%$ \\
\hline \multirow[t]{2}{*}{5} & 7.88 & 7.00 & 0.88 \\
\hline & $53 \%$ & $47 \%$ & $6 \%$ \\
\hline \multirow[t]{2}{*}{6} & 8.50 & 6.50 & 2.00 \\
\hline & $57 \%$ & $43 \%$ & $14 \%$ \\
\hline \multirow[t]{2}{*}{7} & 7.63 & 7.50 & 0.13 \\
\hline & $50 \%$ & $50 \%$ & $0 \%$ \\
\hline \multirow[t]{2}{*}{8} & 7.00 & 5.88 & 1.13 \\
\hline & $54 \%$ & $46 \%$ & $9 \%$ \\
\hline \multirow[t]{2}{*}{9} & 5.88 & 6.63 & -0.75 \\
\hline & $47 \%$ & $53 \%$ & $-6 \%$ \\
\hline \multirow[t]{2}{*}{10} & 5.63 & 6.88 & -1.25 \\
\hline & $45 \%$ & $55 \%$ & $-10 \%$ \\
\hline \multirow[t]{2}{*}{11} & 6.25 & 6.63 & -0.38 \\
\hline & $49 \%$ & $51 \%$ & $-2 \%$ \\
\hline \multirow[t]{2}{*}{12} & 6.13 & 7.25 & -1.13 \\
\hline & $46 \%$ & $54 \%$ & $-8 \%$ \\
\hline \multirow[t]{2}{*}{13} & 6.88 & 9.00 & -2.13 \\
\hline & $43 \%$ & $57 \%$ & $-14 \%$ \\
\hline \multirow[t]{2}{*}{14} & 7.38 & 5.50 & 1.88 \\
\hline & $57 \%$ & $43 \%$ & $14 \%$ \\
\hline \multirow[t]{2}{*}{15} & 7.00 & 5.63 & 1.38 \\
\hline & $55 \%$ & $45 \%$ & $10 \%$ \\
\hline \multirow[t]{2}{*}{16} & 6.63 & 6.75 & -0.13 \\
\hline & $50 \%$ & $50 \%$ & $0 \%$ \\
\hline \multirow[t]{2}{*}{17} & 5.38 & 5.13 & 0.25 \\
\hline & $51 \%$ & $49 \%$ & $2 \%$ \\
\hline \multirow[t]{2}{*}{18} & 8.13 & 6.63 & 1.50 \\
\hline & $55 \%$ & $45 \%$ & $10 \%$ \\
\hline \multirow[t]{2}{*}{ Total } & 132.22 & 128.53 & 3.69 \\
\hline & $51 \%$ & $49 \%$ & $2 \%$ \\
\hline
\end{tabular}

Table 3 Overall strategic balance and by factor Source: Own Elaboration

Graph 2 shows the impact of the strategic balance by variable and its contribution to the overall strategic balance, on the right side of the graph those variables with a positive strategic balance and on the left side of the graph those variables that represent a risk with a negative strategic balance. 
Balance estratégico

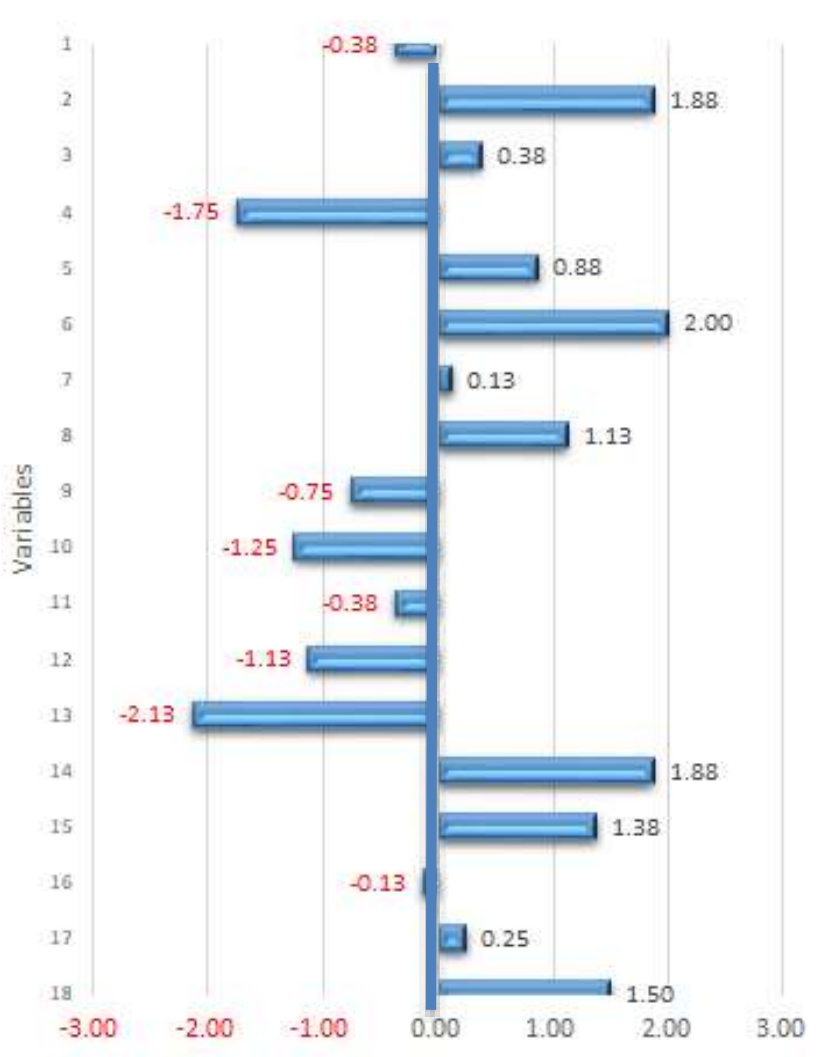

Graphic 2 Impact of strategic balance by variable Source: Own Elaboration

Graph 3 below shows the overall strategic balance

Overall strategic balance

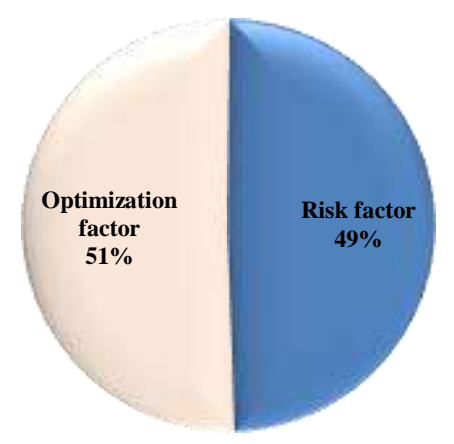

Graphic 3 Global strategic balance

Source: Own Elaboration

Graphs 4 and 5 show the variables that present the strongest optimization factor and the variable that represents the risk factor with the greatest vulnerability in the global balance of strategic competitiveness of San Mateo Atenco's footwear manufacturers, Plaza Azul.

\section{Strength of the commercial network}

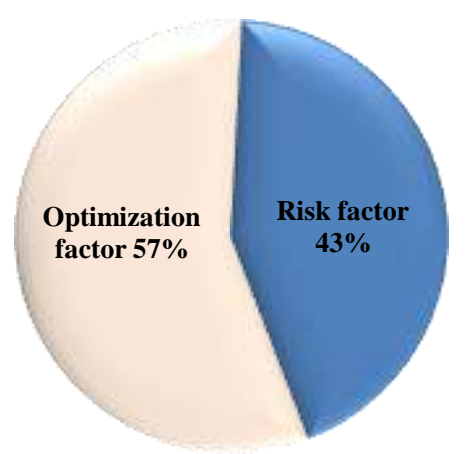

Graphic 4 Optimization factor of higher robustness Source: Own Elaboration

\section{Dependence on customers}

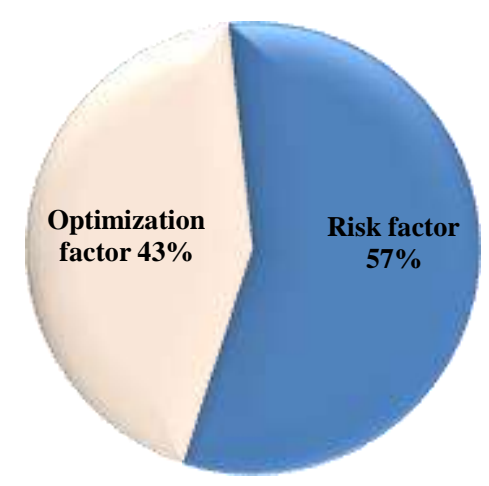

Graphic 5 Risk factor of greatest vulnerability Source: Own Elaboration

Figures 6 and 7 show the variables with important optimization factors, which represent the company's strengths.

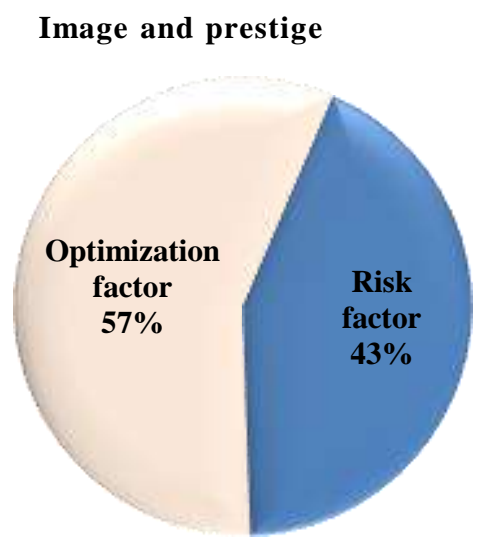

Graphic 6 Balance of image and prestige Source: Own Elaboration 


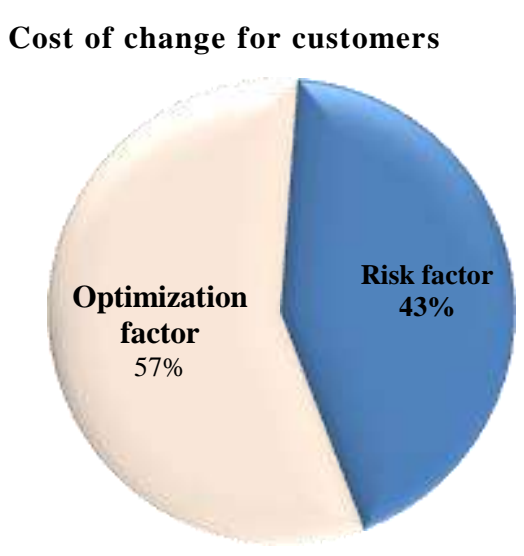

Graphic 7 Balance of Cost of Change for customers Source: Own Elaboration

Graphs 8 and 9 show the variables with risk factors that should be addressed.

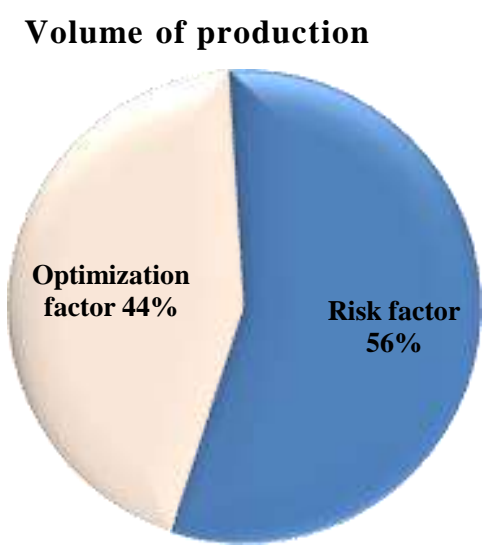

Graphic 8 Balance of Volume of production Source: Own Elaboration

\section{Barriers to enterprise mobility}

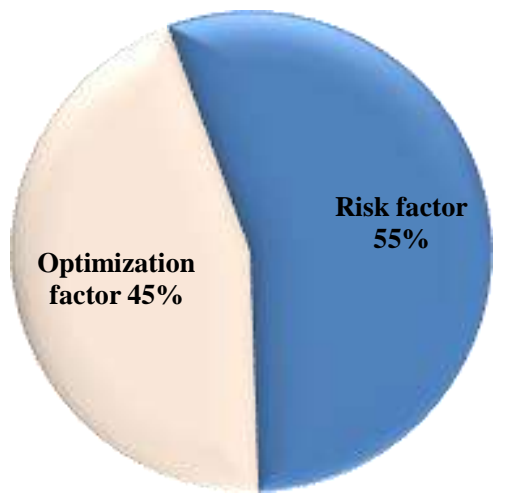

Graphic 9 Balance of Barriers to enterprise mobility Source: Own Elaboration

Finally, the SWOT Matrix, Table 4, shows the most representative elements of the situational analysis based on the results obtained.

\begin{tabular}{|c|c|c|}
\hline & & \\
\hline $\begin{array}{l}\text { Factors } \\
\text { internal }\end{array}$ & $\begin{array}{l}\text { F1. It has a large } \\
\text { customer base. } \\
\text { F2. It has a solid } \\
\text { image and wide } \\
\text { prestige. } \\
\text { F3. It has a wide } \\
\text { range of } \\
\text { suppliers. }\end{array}$ & $\begin{array}{l}\text { D1. There are no } \\
\text { effective } \\
\text { competitive } \\
\text { strategies. } \\
\text { D2. There is } \\
\text { obsolete and } \\
\text { insufficient } \\
\text { machinery. } \\
\text { D3. Limited } \\
\text { production } \\
\text { capacity. } \\
\text { D4. Limited use } \\
\text { of social } \\
\text { networks. }\end{array}$ \\
\hline Opportunities & & D1O2. develop \\
\hline $\begin{array}{l}\text { O1. Growth in } \\
\text { demand in the } \\
\text { footwear sector. } \\
\text { O2. Support } \\
\text { from } \\
\text { government } \\
\text { entities to } \\
\text { strengthen } \\
\text { SMEs. } \\
\text { O3. Increase in } \\
\text { online sales. }\end{array}$ & 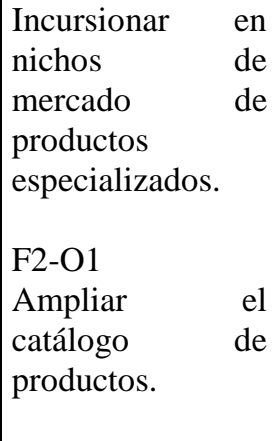 & $\begin{array}{l}\text { competitive } \\
\text { strategies with } \\
\text { the support of } \\
\text { government } \\
\text { entities. } \\
\text { D2D3O2. Obtain } \\
\text { government } \\
\text { support for the } \\
\text { purchase of new } \\
\text { machinery. }\end{array}$ \\
\hline $\begin{array}{l}\text { Threats } \\
\text { A1. Increase of } \\
\text { national and } \\
\text { international } \\
\text { competitors. } \\
\text { A2. Increase in } \\
\text { the price of raw } \\
\text { materials. } \\
\text { A3. Increase of } \\
\text { taxes in tariff } \\
\text { rates for both } \\
\text { machinery } \\
\text { purchases and } \\
\text { exports. }\end{array}$ & $\begin{array}{l}\text { F2 A1. Design of } \\
\text { strategies to } \\
\text { reinforce its } \\
\text { image } \\
\text { prestige. } \\
\text { F3 A2. Carry out } \\
\text { supplier } \\
\text { development in } \\
\text { order to increase } \\
\text { its } \\
\text { competitiveness.. }\end{array}$ & $\begin{array}{l}\text { D3 A1. Establish } \\
\text { alliances between } \\
\text { producers. } \\
\text { D4 A1. Enter into } \\
\text { marketing } \\
\text { through social } \\
\text { networks. }\end{array}$ \\
\hline
\end{tabular}

Table 4 SWOT Matrix

Source: Own Elaboration

\section{Conclusions}

By applying the proposed procedure and using the described techniques, it was possible to determine the strategic competitive position of the footwear producers of Plaza Azul. The overall strategic balance with $90 \%$ confidence is between 2.952 and 4.42. The ideal strategic balance between the opportunity factors and the risk factor in each case is not $50 \%$ and $50 \%$ between them, but rather, the former should exceed the latter, in search of improved operating conditions. In this case, it can be observed that the strategic balance, even when the difference is minimal, only $2 \%$, the footwear manufacturers are optimizing the use of their strategic capabilities. 
The analysis by variable showed that the potentialities present in the highest optimization factors are found in: the strength of the commercial network, image and prestige, cost of change for customers and forward integration of suppliers. On the other hand, the variables where the main competitive weaknesses are determined are: dependence on customers, followed by production volume and customer loyalty.

Strategic interest in remaining in the sector, since it is precisely in the evaluation of this variable where it becomes clear that there is a very important area of opportunity, because it is necessary to take into account the realization of an adequate strategic planning, where competitive strategies are determined based on the capabilities and resources of the company.

In order to increase the strategic competitiveness of the Plaza Azul footwear industry in San Mateo Atenco, State of Mexico, the strategies set out in the SWOT matrix are proposed, based on the results of this research. In the first quadrant of the "Max-Max" F1-O1 matrix, it is proposed to enter niche markets for specialized products, offering high value-added products, such as orthopedic shoes and shoes for diabetics, which would be marketed through the company's extensive distribution network.

In the same quadrant, the second proposed strategy F2-O1 is to expand the product catalog; the increase in demand for domestic footwear is imminent, consumers' tastes and needs are changing, so having a greater supply can help expand the market; an unattended market niche is meeting the demands of consumers of special sizes with exclusive designs. Consumers demand products that meet their needs and are backed by manufacturers recognized for their quality and design. As can be seen, the proposed strategies are aggressive towards competitors, since they maximize opportunities with the company's strengths. The "Min-Max" quadrant D1-O2 shows strategies that seek to counteract the company's weaknesses by taking advantage of the opportunities offered by the government. It is imperative to develop competitive strategies for which it is proposed to approach the Ministry of Economy, which provides support through the Program for Productivity and Industrial Competitiveness (PPCI).
The development of strategic thinking is essential to determine the competitive strategy such as competing on costs, competing through differentiation or specializing in a market segment. The second strategy proposed in this quadrant is D2-D3-O2. Access the Micro, Small and Medium Enterprise Support Fund (Fondo PYME) to grant preferential economic support for the modernization and/or purchase of machinery, since, in order to be cost competitive, the use of functional machinery is vital. With respect to the "MaxMin" quadrant F2-A1, the proposals seek to enhance the company's strengths in order to minimize the threats that are present in the industry.

It is proposed to reinforce its image and prestige in order to establish a barrier for competitors. The creation of a distinctive image for their brand, as well as the design of a logo and slogan that distinguishes and represents them, taking advantage of the image and prestige they have, would translate into a competitive advantage over the competition that is growing day by day. As a second strategy F3$\mathrm{A} 2$, carry out the development of suppliers in order to increase their competitiveness. Establishing strategic alliances with suppliers in the region, training them in the processes for the development of the value chain.

To conclude, in the "Min-Min" quadrant D3-A1, the strategies proposed below seek to build strengths that will allow the company to implement defensive strategies. It is proposed to establish temporary or permanent alliances between producers in San Mateo Atenco to face the competition and respond to demand, since a present problem is the low installed capacity. The second strategy proposed in this quadrant corresponds to D4-A1. The situation caused by SARS-CoV-2, which causes the disease COVID-19, has forced government authorities to establish an epidemiological risk traffic light to move towards a new normality, which unfortunately is not yet certain to be achieved in the short term. This situation restricts mobility and face-to-face commerce, so the use of e-commerce becomes a solution to this problem. The implementation of the strategies described above will increase the strategic competitiveness of the footwear manufacturers of Plaza Azul in San Mateo Atenco, Edo. de México. 


\section{References}

Alegría, A. (19 de mayo de 2020). Industria del calzado suma pérdidas por 2 mil 800 mdp en 60 días. La Jornada, pág. Sección Economía. Recuperado de: https://www.jornada.com.mx/ultimas/economia /2020/05/19/industria-del-calzado-suma-2-mil800-mdp-en-60-dias-de-paralizacion-9080.html

Betancourt, B. (2014). Análisis Sectorial y Competitividad. Bogotá: Ecooe Ediciones. Recuperado de: https://elibro.net/es/lc/ittoluca/titulos/130462. p.230.

Esquivel, E. (08 de junio de 2015). Crisis de la industria del calzado provocada por el comercio desleal de China. SDP Noticias. Recuperado de: https://www.sdpnoticias.com/

García, J., Prieto, R., \& Sanz, D. (2014). Factores de Competitividad Organizacional. Su Gestión para la Sostenibilidad Empresarial. VI Jornadas Científicas Nacionales Dr. Gregorio Hernández. "Visión transdisciplinaria e integradora de la investigación".

Hamel, G., \& Prahalad, C. (julio de 2005). Propósito estratégico. Harvard Business Review, La organización de Alto desempeño.

Kerber, V. (2002). China y el calzado mexicano. Revista Comercio Exterior (Bancomext), 52 (10), 900-906. ISSN 23958324.

Munch, L., \& Ángeles, E. (1998). Métodos y Técnicas de Investigación. México: Trillas.

Olvera, D. (15 de febrero de 2018). El comercio en México con Rusia y China creció con Trump; alertan que EU va a tomar represalias. Recuperado de: https://www.sinembargo.mx/

Pérez, J. (17 de marzo de 2020). Cancelan firma de acuerdo de exportación de calzado por coronavirus. Heraldo. Estado de México, pág. Sección Municipios.

Porter, M. (2007). La ventaja competitiva de las naciones. Harvard Business Review. América Latina, 85 (11), 69-95. ISSN 0717-9952
Publishing, Marketing. (2007). La Ventaja Competitiva. Madrid, España: Ediciones Díaz de Santos S.A. Recuperado de: https://elibro.net/es/lc/ittoluca/titulos/52925. p. 26-28

Ramírez, J. L. (2009). Procedimiento para la elaboración de un análisis FODA como una herramienta de planeación estratégica de las empresas. (IIESCA, Ed.) Ciencia Administrativa, 54-61. Recuperado de: http://www.uv.mx/iiesca/files/2012/12/herramie nta2009-2.pdf

Rios, E. (junio 17 2020) "Zapateros en crisis tras cierre de negocios por Covid-19”. La Jornada. Sección Economía, Recuperado de: https://www.elsoldetoluca.com.mx/local/zapate ros-en-crisis-tras-cierre-de-negocios-por-covid19-5375515.html

Sáez de Viteri, A. (2000). El potencial competitivo de la empresa: Recursos, capacidades, rutinas y procesos de valor añadido. Investigaciones Europeas de Dirección y Economía de la Empresa, Vol. 6(3), 71-86. Recuperado de:

https://scholar.google.es/scholar?hl=es\&as_sdt $=0 \% 2 \mathrm{C} 5 \mathrm{\& q}=\mathrm{EL}+\mathrm{POTENCIAL}+\mathrm{COMPETITI}$ $\mathrm{VO}+\mathrm{DE}+\mathrm{LA}+\mathrm{EMPRESA} \% 3 \mathrm{~A}+\mathrm{RECURSOS} \%$ 2C+CAPACIDADES $\% 2 \mathrm{C}+\mathrm{RUTINAS}+\mathrm{Y}+\mathrm{PR}$ OCESOS+DE+VALOR+A\%C3\%91ADIDO\& btnG=

Secretaría de Economía. Recuperado 10 junio 2019 https://www.gob.mx/se/articulos/conocemas-sobre-la-industria-del-calzado/

Zarur, O. (1993). Apertura comercial, modernización empresarial y su impacto sobre la industria del calzado en México. Revista Gestión y Estrategia, 27 (3), 68-71. ISSN 01888234.

Zenteno, B., Aguirre, B., Calderón, R.\& Ordoñez, H. (2019). Estrategias de la Mezcla de Mercadotecnia de la Industria del Calzado en San Mateo Atenco Plaza Azul. JournalBusiness Administration and Business Economics Marketing Accounting, 3 (5), 24-37. ISSN 2531-3002. 